\title{
Opzettelijk tekortschieten en risico's van contractuele remedies: een balans van belangen voor schuldeiser en schuldenaar
}

\author{
Mr.drs. M. van Kogelenberg*
}

\section{Inleiding}

Bijna vijf jaar geleden promoveerde ik op het proefschrift Motive Matters, waarin de figuur van de opzetteliike tekortkoming in de nakoming van een contractuele verbintenis en een verkenning van de mogelijke contractenrechtelijke reacties van de schuldeiser daarop vanuit rechtsvergelijkend perspectief centraal stonden. ${ }^{1}$ Tijdsverloop schept afstand tot het geschrevene, hetgeen ruimte creëert voor een kritische terugblik.

Deze terugblik (par. 2) koppel ik in deze bijdrage aan een drietal ontwikkelingen sinds het verschijnen van het proefschrift, waarbij de schuldenaar op een of andere wijze opzettelijk de contractuele vertrouwensband doorbreekt of lijkt te doorbreken: de overboeking van vluchten (par. 3), de praktijk van onderverhuur van woningen in een toeristische omgeving via bijvoorbeeld Airbnb (par. 4) en de positionering van het recht op nakoming of vervangende schadevergoeding bij kleine(re) wanprestaties aan de hand van een recent arrest van de Hoge Raad (par. 5). In het laatste geval benadruk ik nu alvast dat in het bedoelde arrest de wanprestant niet opzettelijk tekortschiet, maar dat dit gevalstype een risico in zich draagt dat dit zou kunnen gebeuren. Deze gevalstypen komen in vergelijkbare vorm ook in mijn proefschrift voorbij, maar krijgen in deze bijdrage in onderlinge samenhang een actueel vervolg, waarbij ook nadrukkelijk de positie van de tekortschietende wanprestant ter sprake komt. Ik sluit af met een conclusie (par. 6).

\footnotetext{
Mr. drs. M. van Kogelenberg is werkzaam als universitair docent privaatrecht bij het Molengraaff Instituut voor Privaatrecht van de Universiteit Utrecht.

1. M. van Kogelenberg, Motive Matters! An Exploration of the Notion 'Deliberate Breach of Contract' and Its Consequences for the Application of Remedies, Cambridge: Intersentia 2013 (bewerkte handelseditie proefschrift 2012). De ideevorming in het proefschrift is in artikelvorm weergegeven in M. van Kogelenberg, Deliberate Breach of Contract and Consequences for Remedies: Exploration of a Neglected Area in the Law of Contract, Maastricht Journal of European and Comparative Law 2014, p. 141-162; M. van Kogelenberg, Opzettelijke contractbreuk en contractuele remedies: een onderbelicht terrein, Contracteren 2014, p. 3-13.
}

De bespreking van deze ontwikkelingen in het licht van het proefschrift noopt tot een korte reflectie op het begrip opzettelijke tekortkoming, maar ook op de mogelijke remedies naar aanleiding daarvan. Moeten deze remedies gericht zijn op herstel of compensatie? Zijn zij met andere woorden vooral 'reactief ? Of moeten deze remedies ook een meer proactief karakter hebben en gericht zijn op preventie van ongewenst gedrag - het voorkomen van wanpresteren dus - of zelfs op bestraffing van de wanprestant dan wel genoegdoening van het 'slachtoffer'? Bij de vormgeving van deze remedies speelt tevens een rol dat het evenwicht tussen de positie van schuldeiser en schuldenaar gewaarborgd moet blijven: ook de schuldeiser mag immers geen misbruik maken van zijn positie, ook niet bij een geconstateerde opzettelijke tekortkoming.

\section{Motive matters! Or does it? Een korte terugblik op het proefschrift}

\subsection{Thematiek}

In mijn (Engelstalige) proefschrift onderzoek ik de figuur van het opzettelijk tekortschieten in de nakoming van een contractuele verbintenis of opzettelijke contractbreuk (deliberate breach of contract). Het gaat om een bijzondere vorm van toerekenbaar tekortschieten van de schuldenaar, waarbij de schuldenaar bewust tekortschiet in de nakoming van een op hem rustende contractuele verbintenis met het oog op het verkrijgen van geldelijk voordeel, dan wel met het oog op het vermijden van geldelijk nadeel. ${ }^{2}$ In mijn proefschrift bespreek ik eerst de door mij gehanteerde werkdefinitie vanuit verschillende perspectieven. Het blijkt dat met name in de Verenigde Staten langer en vaker is nagedacht over deze specifieke rechtsfiguur. Vanuit rechtseconomisch perspectief kent men de figuur 'efficient breach' ofwel efficiënte wanprestatie. ${ }^{3}$ De 'efficiënte' wanprestatie valt onder de door mij gehanteerde werkdefinitie en is volgens een aantal rechtseconomen onder

2. Van Kogelenberg 2013, hoofdstuk 3.

3. Zie bijv. B.E. Adler, Efficient Breach Theory through the Looking Glass, New York University Law Review (83) 2008, p. 1679-1725. 


\section{Maandblad \\ Vermogensrecht}

omstandigheden te rechtvaardigen, namelijk - kort gezegd in het geval dat de schuldeiser volledig gecompenseerd wordt voor de gevolgen van deze wanprestatie. In deze rechtsfiguur is dus van belang te onderkennen dat de schuldenaar ervoor kiest te wanpresteren en ook ervoor kiest de oorspronkelijke schuldeiser financieel daarvoor te compenseren. Cruciaal voor het accepteren van deze rechtsfiguur is de veronderstelling dat bezien vanuit de schuldeiser een contractuele verbintenis in essentie niet zozeer een recht behelst op de afgesproken prestatie, maar uitsluitend een recht op de waarde van de afgesproken prestatie. Deze voorstelling van het obligatoire contract is in rechtsstelsels met een common law-achtergrond, met name in de Verenigde Staten, meer geaccepteerd dan in rechtsstelsels met een zogenaamde civil law-achtergrond, zoals het Nederlandse recht. Wanneer de schuldeiser immers een recht op nakoming heeft en kan uitoefenen bij wanprestatie, kan de schuldenaar geen gebruik meer maken van de 'efficient breach'.

Interessant wordt het wanneer men in ogenschouw neemt dat men ook in de Verenigde Staten vormen van opzettelijke wanprestatie kent die niét 'efficiënt' zijn. Op dat ogenblik wordt niet meer gesproken van 'efficient breach', maar van 'willful' of 'opportunistic breach', bijvoorbeeld wanneer de schuldenaar de oorspronkelijke eiser niet of niet afdoende compenseert. ${ }^{4}$ In mijn proefschrift hanteer ik voorts de meer neutrale term 'deliberate breach', omdat de reeds genoemde termen een bepaalde en specifieke invulling hebben gekregen in het betreffende stelsel.

Voorts bespreek ik in mijn proefschrift in verschillende rechtsstelsels bestaande voorbeelden van 'deliberate breach' in jurisprudentie, waarbij ik tevens het bestaande sanctiearsenaal van de schuldeiser - het gaat veelal om een onderzoek naar de rechten op nakoming, schadevergoeding en ontbinding in vooral Anglo-Amerikaans recht en de belangrijkste Europese continentale rechtsstelsels en het Nederlandse recht - onder de loep neem. ${ }^{5}$

In het meer normatieve gedeelte van mijn proefschrift kom ik aan de hand van deze analyse tot de gevolgtrekking dat dit arsenaal hier en daar tekortschiet en formuleer ik een aantal aanbevelingen om het sanctiearsenaal van de schuldeiser te versterken in het geval van opzettelijk tekortschieten. Aangezien het arsenaal in de verschillende stelsels niet overal hetzelfde is, verschilt het per stelsel welke door mij gesuggereerde veranderingen het meest opportuun zijn. Voor het Nederlandse recht benadruk ik bijvoorbeeld het belang van een sterk recht op nakoming en geef ik een suggestie om bijvoorbeeld het element opzet mee te laten wegen bij het toekennen van winstafdracht op grond van art. 6:104 van het Burgerlijk Wetboek (BW). Tot slot tracht ik via een aantal 'case studies' te achter-

4. Zie o.m. R.A. Posner, Let Us Never Blame a Contract Breaker, Michigan Law Review (107) 2009, p. 1349-1364; S. Thel \& P. Siegelman, Willfulness versus Expectation: A Promise-Based Defense of Willful Breach Doctrine, Michigan Law Review (107) 2009, p. 1517-1532.

5. Van Kogelenberg 2013, hoofdstuk 4. halen hoe dit veranderde sanctiearsenaal de uitkomst van een situatie waarbij 'deliberate breach' een rol speelt, zou beïnvloeden. ${ }^{6}$

\subsection{Reflectie}

Een mogelijk ingewikkeld punt van het rechtsvergelijkend ingestoken proefschrift is dat de figuur van het opzettelijk tekortschieten in het Nederlandse recht niet (meer) als zodanig expliciet wordt genoemd. ${ }^{7}$ Ons stelsel gaat er immers van uit dat de schuldeiser nakoming kan vorderen van de contractuele verbintenis, ook na wanprestatie. Bij de uitoefening van dit recht is het motief voor wanprestatie niet direct van belang. Bij het vorderen van schadevergoeding wegens wanprestatie is toerekenbaarheid de toetssteen, 'opzet' wordt daarin niet als criterium genoemd. Voor het inroepen van ontbinding is het motief evenmin relevant, toerekenbaarheid is immers niet vereist. En hoe - men kan dat gevoeglijk niet alleen in situaties van bijvoorbeeld bedrog en onrechtmatige daad, maar ook in het strafrecht terugzien - komt men over de enorme hobbel van het bewijs van het opzet heen om überhaupt toe te komen aan deze vraag of en hoe er anders gereageerd moet worden op een dergelijk opzettelijk tekortschieten ten opzichte van een niet-opzettelijk tekortschieten?

Natuurlijk heb ik in mijn proefschrift deze kwesties geadresseerd. Niettemin kan ik mij - enige jaren na dato - wel voorstellen dat de thematiek van afstand een wat al te academisch karakter ademt om aantrekkelijk te zijn voor de rechtspraktijk. In deze bijdrage tracht ik daar iets aan te doen, juist ook om vanuit het perspectief van het opzettelijk tekortschieten te kunnen laten zien dat contractuele remedies schuldeiser én schuldenaar kunnen helpen hun positie te bepalen en hun gedrag daardoor te laten sturen.

In deze bijdrage haal ik de positie van de opzettelijk tekortschietende wanprestant wat duidelijker naar voren, in die zin dat ik zal trachten ook zijn belangen te duiden: de schuldenaar mag geen onnodige druk leggen op de contractuele band, die tevens een vertrouwensband behelst, door te dreigen met wanprestatie of door bewust wanprestatie te plegen met het oog op geldelijk gewin of het vermijden van financieel nadeel. Maar ook zal duidelijk worden dat de schuldeiser niet mag worden verleid tot onterecht slachtoffergedrag ten gevolge van wanprestatie door de schuldenaar. Met drie actuele voorbeelden die ik ook in mijn proefschrift aan bod heb laten komen, wil ik dit bijzondere evenwicht nader illustreren.

\section{Overboeking van passagiersvluchten: een gevalstype opzettelijk tekortschieten met strenge sancties of een ander perspectief?}

In mijn proefschrift behandel ik als voorbeeld van een opzettelijke wanprestatie onder meer het verschijnsel overboeking van

6. Van Kogelenberg 2013, hoofdstuk 5 en 6.

7. In het oud BW waren er wel bepalingen die op deze notie betrekking hadden: art. 1283 en 1284 OBW; zie ook Van Kogelenberg 2013, par. 4.4.8. 
een passagiersvlucht vanuit contractenrechtelijk perspectief. ${ }^{8}$ Recentelijk vond in de Verenigde Staten een incident plaats dat direct samenhing met deze problematiek. ${ }^{9}$

Op 10 april 2017 was een vlucht van maatschappij United Airlines van Chicago naar Louisville overboekt. Alle vliegtuigstoelen waren bezet. Toen het vliegtuig vol zat, bleken er medewerkers van de betreffende luchtvaartmaatschappij mee te willen dan wel moeten vliegen. $\mathrm{Zij}$ konden er niet meer bij en er moesten dus mensen uit. De luchtvaartmaatschappij probeerde op vrijwillige basis passagiers uit te kopen. Dat leek goed te gaan, maar men moet bedenken dat deze voorstellen gedaan werden toen mensen hun plaats in het vliegtuig al hadden ingenomen, hetgeen de bereidwilligheid verkleinde. Het latere 'slachtoffer' ging in eerste instantie wel akkoord met een vrijwillige uitkoopregeling, totdat hij vernam dat hij pas de volgende dag naar zijn eindbestemming kon vliegen. Hij wilde terugkomen op zijn toezegging en bleef zitten in zijn vliegtuigstoel. Vervolgens beriep de luchtvaartmaatschappij zich op haar (contractuele) recht, dat inhield dat zij in geval van overboeking passagiers ook gedwongen van boord mocht halen. Vervolgens werd de bewuste passagier met geweld van boord verwijderd, waarbij de man verwondingen opliep. Deze gebeurtenis zorgde voor veel discussie; zo werd bijvoorbeeld het toegepaste geweld in verband gebracht met de etnische achtergrond van de passagier. ${ }^{10}$

De vraag is of en hoe uit dit voorbeeld een opzettelijk tekortschieten kan worden gedestilleerd en hoe hierop door de mogelijke reacties van de schuldeiser (de passagier) zouden kunnen worden vormgegeven. Het probleem laat zich in eerste instantie vrij eenvoudig schetsen. De aanstaande passagier koopt een ticket voor een vlucht van A naar B op moment X. Hij verkeert dan in de veronderstelling dat hij in ruil voor de prijs van het gekochte ticket een recht heeft verkregen om op moment $\mathrm{X}$ van $\mathrm{A}$ naar $\mathrm{B}$ gebracht te worden. Als het zover is, mag de passagier niet mee en daarmee schendt de luchtvaartmaatschappij opzettelijk haar verplichting - naar hieronder blijkt uit bedrijfseconomische overwegingen - om de passagier van A naar B op moment $X$ te vervoeren. Voordat op de mogelijke reacties van de passagier wordt ingegaan, past hier eerst een moment van reflectie op de juridische inbedding van deze praktijk.

Om een idee te krijgen van een ander perspectief op deze problematiek is het goed om het evenwicht in de positie van schuldeiser (klant) en schuldenaar (luchtvaartmaatschappij) tegen de economische en maatschappelijke context in ogenschouw te nemen. De praktijk van de burgerluchtvaart brengt met zich dat het nogal eens voorkomt dat passagiers niet

8. Van Kogelenberg 2013, par. 4.4.6 en 6.7.

9. Zie bijv. edition.cnn.com/2017/04/10/travel/passenger-removed-unitedflight-trnd/index.html; www.nytimes.com/2017/04/10/business/unitedflight-passenger-dragged.html.

10. Zie www.nytimes.com/2017/04/11/world/asia/united-airlines-passengerdragged-china.html. komen opdagen voor hun vlucht. Luchtvaartmaatschappijen kunnen het zich vanwege de grote concurrentie op deze markt niet veroorloven om te veel en te vaak het risico te lopen dat er met te veel onbezette stoelen gevlogen wordt, althans niet tegen de vaak lage prijzen van de tickets. Daarom worden er voor een bepaalde vlucht meer tickets verkocht dan er stoelen zijn. De prijzen voor veel tickets zijn in het algemeen de afgelopen decennia steeds verder gedaald. ${ }^{11}$ Dit betekent dat zij er belang bij hebben dat de vliegtuigen zo vol mogelijk zitten en dat mogelijke overboeking een weloverwogen risico is dat zij moeten nemen om hun bedrijf te kunnen continueren. Daar komt bovendien bij dat klanten in het algemeen de verlaging van ticketprijzen waarderen, omdat zij daarmee hun mobiliteit kunnen vergroten. Dit is ook onderdeel van de overeenkomst tussen de passagier en de luchtvaartmaatschappij.

Klanten van luchtvaartmaatschappijen kopen dus geen ticket dat hun recht geeft op verplaatsing van A naar B op een bepaald moment, maar een voorwaardelijk recht, waarbij de luchtvaartmaatschappij zich verplicht de klant op moment $\mathrm{X}$ van A naar B te vliegen, onder de voorwaarde dat in geval van overboeking niet alle passagiers komen opdagen voor hun vlucht. Dat betekent dat klanten geen garantie op een zitplaats in het vliegtuig kunnen afleiden uit hun ticket. Het is voorstelbaar dat zij een ticket kunnen kopen waarbij zij die garantie wél hebben, maar dan ligt het in de rede dat de ticketprijs hoger uitvalt, omdat een rendabele en zelfs aanvaardbare exploitatie van een luchtvaartmaatschappij een grotere uitdaging wordt. Van belang is wel hier op te merken dat klanten wel dienen te worden gecompenseerd voor hun gemiste vlucht. Ik wijs bijvoorbeeld op EG-Verordening 261/2004, die een vergoedingsregime bevat. ${ }^{12}$ Niet altijd bieden luchtvaartmaatschappijen de compensatie waartoe zij op grond van de verordening verplicht zijn, vooral niet bij vertraagde vluchten. ${ }^{13}$ Het lijkt er bovendien op dat de verordening ervan uitgaat dat overboeking een vorm van ongewenst gedrag is dat deugdelijk geadresseerd moet worden door de luchtvaartmaatschappij. In de praktijk is het risico van overboeking juist een bewust en strategisch beleid van de luchtvaartmaatschappij. Bovendien bieden luchtvaartmaatschappijen in geval van overboeking ter plaatse vaak zelf - of dat nu verplicht of bedrijfsstrategie is - geld of hotelovernachtingen aan volgens de verordening en wel vóórdat de passagiers zijn ingestapt. ${ }^{14}$ Uit de loop van de gebeurtenissen in het aangehaalde recente voor-

11. Zie bijv. U.S. Department of Transportation, BTS 24-16, Tuesday, April 26, 2016, p. 8 (beschikbaar via www.transportation.gov/briefingroom).

12. Verordening (EG) $261 / 2004$ van het Europees Parlement en de Raad van 11 februari 2004, meer in het bijzonder art. 4 en 7.

13. Passagiers krijgen van het Hof van Justitie daarom ook in concrete zaken in het algemeen steeds bescherming. Zie bijv. recentelijk HvJ EU 11 mei 2017, ECLI:EU:C:2017:359 (Krijgsman/SLM), maar ook het belangrijke arrest van HvJ EU 19 november 2009, ECLI:EU:C:2009:716 (Sturgeon).

14. Voor de luchtvaartmaatschappij gold in 2016 dat 3765 van de meer dan 86 miljoen passagiers van overboekte vluchten werden geweigerd. 62.895 passagiers werden vrijwillig uitgekocht. Zie www.transportation.gov/ sites/dot.gov/files/docs/resources/individuals/aviation-consumerprotection/2017MarchATCR.pdf. 


\section{Maandblad \\ Vermogensrecht}

beeld lijkt de onhandige timing van de 'uitkoopprocedure' meer van invloed op de escalatie te zijn geweest dan de overboeking zelf. De loop der gebeurtenissen laat zien dat men in ieder geval ook in de Verenigde Staten verbaasd leek over de gang van zaken. ${ }^{15}$

Als de contractuele verplichting echter zo wordt ingekleed dat passagiers geen ticket voor een specifieke vlucht kopen, maar alleen een recht op verplaatsing van $A$ naar $B$, is de vraag veeleer of zij voldoende op de hoogte worden gebracht van het product dat zij aanschaffen en of zij achteraf voldoende worden gecompenseerd als er sprake is van overboeking. Als zij adequaat ex ante worden geïnformeerd dat zij, voordat de geplande en geboekte vlucht plaatsvindt, kunnen worden uitgekocht - al dan niet op vrijwillige basis - en adequaat worden gecompenseerd, dan verdwijnt de vraag naar een reactie op mogelijke opzettelijke wanprestatie naar de achtergrond.

Uit dit actuele voorbeeld wordt duidelijk dat in deze specifieke omstandigheden de belangen van beide partijen zowel in juridische als in economische en maatschappelijke context moeten worden bezien. Het perspectief van het opzettelijk tekortschieten lijkt dan in dit geval wat naar de achtergrond te verschuiven. Een aanvaardbaar evenwicht tussen de belangen van de schuldenaar (de luchtvaartmaatschappij) - vooruitzichten op rendabele exploitatie en tevreden klanten - en die van de schuldeiser (de klant) - betaalbare vliegtickets en waar voor je geld - kan daarom in dit geval worden bereikt als de klant afdoende wordt geïnformeerd over het product dat wordt aangeboden en adequaat wordt gecompenseerd.

\section{Contractueel verboden onderverhuur voor} toeristen en mogelijke reacties van de schuldeiser

Een voorbeeld waarbij belangen van schuldeiser en schuldenaar in het kader van de contractenrechtelijke remedies eveneens afweging verdienen, is de praktijk van onderverhuur van woningen en kamers via Airbnb. Het gaat mij hier niet om de problematiek van eigenaren van woningen die deze aanbieden via Airbnb en daarmee mogelijkerwijs verschillende publiekrechtelijke regels schenden (ten aanzien van belastingen, veiligheid en dergelijke). Ik richt mij op huurders van woningen die in strijd met de huurovereenkomst die zij hebben gesloten met de eigenaar/verhuurder van de woning, deze woning via Airbnb of een ander digitaal platform aanbieden aan toeristen. Daarmee plegen zij bewust en opzettelijk wanprestatie ten opzichte van de eigenaar van de woning. ${ }^{16}$

Het belang van deze problematiek voor deze bijdrage lijkt duidelijk. De vraag is immers welke mogelijkheden de schuldeiser - de eigenaar/verhuurder - heeft en zou moeten hebben om hiertegen op te treden. Daarbij is wederom belangrijk zowel de belangen van de schuldenaar - de onderverhuurder - als de maatschappelijke belangen niet uit het oog te verliezen. Twee

15. Zie de artikelen in noot 9

16. Zie ook M. van Kogelenberg, Onderverhuren via Airbnb? Een riskante bijverdienste voor de onderverhuurder, TvC 2016, afl. 4, p. 151-159. mogelijke remedies zijn daarbij ten minste van belang. Ten eerste ligt de vraag voor of de eigenaar de huurder kan dwingen de gehuurde woning te ontruimen. Daarvoor is het nodig dat de eigenaar de overeenkomst kan ontbinden. Ten tweede kan worden gedacht aan de mogelijkheid om de door de onderverhuurder genoten winst aan de eigenaar te laten betalen.

In mijn proefschrift heb ik al betoogd dat wanneer aannemelijk kan worden gemaakt dat de schuldenaar - de onderverhuurder - met het oog op geldelijk gewin de overeenkomst niet nakomt, de rechter de bestaande remedies meer in het voordeel van de schuldeiser zou moeten kunnen uitleggen. Interessant is dat dat in dit geval ook lijkt te gebeuren, in ieder geval ten aanzien van de ontbindings- c.q. ontruimingskwestie. Buiten kijf staat dat in vrijwel elke situatie van verboden onderverhuur in beginsel voldaan is aan de eis van tekortschieten in de nakoming van de overeenkomst. Toerekenbaarheid is daarbij niet vereist. Dat roept de vraag op wat opzettelijk tekortschieten dan nog voor betekenis zou kunnen hebben.

Het blijkt echter dat de rechter in sommige gevallen ook de positie van de schuldenaar expliciet betrekt bij de vraag of de tekortkoming dan ook ontbinding rechtvaardigt en dus ook ontruiming. Zo heeft de rechter ooit geoordeeld dat een moeder van twee kinderen die een gedeelte van haar woning had onderverhuurd via Airbnb niet zomaar op straat kon worden gezet. In dit kader is vooral van belang dat de moeder weliswaar bewust tekortschoot, maar niet met het oog op geldelijk gewin, omdat zij het geld dat zij verdiende nodig had om de (hoge) huur van haar eigen woning te kunnen betalen. Bovendien bleef zij zelf ook in de woning als zij deze gedeeltelijk onderverhuurde, dus zij onttrok ook geen woonruimte aan de (sociale) woningmarkt. We zien hier dus in het kader van de vraag naar het evenwicht in belangen tussen schuldeiser en schuldenaar dat de rechter naast het element 'opzet' ook andere elementen in zijn overwegingen kan betrekken.

Ten aanzien van het vorderen van winstafdracht zien we dat art. 6:104 BW geen zelfstandige grond voor het vorderen van schadevergoeding biedt, maar uitsluitend voorziet in een andere wijze van schadebegroting als de schade moeilijk kan worden begroot. Essentieel is dus wel dat het bestaan van schade aannemelijk wordt gemaakt: ook winstafdracht is een vorm van compensatoire schadevergoeding. De Hoge Raad benadrukt ook dat winstafdracht geen punitief karakter heeft. Niettemin laat de Hoge Raad wel wat ruimte voor het inzetten van deze remedie net buiten het compensatoire terrein. ${ }^{17}$ Het is bijvoorbeeld niet zo dat de schuldeiser aannemelijk moet maken dat de hoogte van de beweerdelijk geleden schade en de genoten winst precies gelijk moet zijn. Het is op dit terrein dat duidelijk wordt dat de eigenaar/verhuurder hier een extra mogelijkheid heeft om op te treden tegen de onderverhuurder als hij aannemelijk kan maken dat hij kosten moet

17. HR 28 juni 2010, ECLI:NL:HR:2010:BM0893, RvdW 2010/771 (Doerga/Stichting Ymere). 
maken om de onderverhuur aan het licht te brengen. ${ }^{18}$ In dat geval kan hij proberen de genoten winst van de onderverhuurder te vorderen. Dit blijft een lastige taak, want het is ook al duidelijk geworden dat als de onderverhuur met een klik op een website of via een eenvoudig telefoontje kan worden ontdekt, deze vordering niet succesvol kan zijn, omdat in dat geval immers geen schade aanwezig is.

Kern van dit voorbeeld is dat wanneer sprake is van puur winstbejag door de onderverhuurder, deze via de contractenrechtelijke remedies ontbinding/ontruiming en mogelijk winstafdracht effectief kan worden aangepakt. Wanneer de motieven voor contractueel verboden onderverhuur genuanceerder liggen, is ook duidelijk dat de rechter daarop anders kan reageren. Dit voorbeeld laat zien dat het Nederlandse privaatrecht op dit terrein de flexibiliteit biedt om ook binnen het kader van de opzettelijke wanprestatie een balans te vinden tussen de belangen van schuldeiser en schuldenaar.

\section{Een beetje zwanger bestaat niet, een beetje tekortschieten wel? Een nieuw arrest van de Hoge Raad}

Het adagium dat belofte schuld maakt, geldt in het Nederlandse contractenrecht in beginsel voor de gehele overeenkomst. Het recht op nakoming - dat als zodanig zoals bekend niet in de wet is opgenomen - is een recht dat voortvloeit uit de overeenkomst zelf. De schuldeiser heeft in beginsel in voorkomende gevallen de vrijheid te kiezen of hij zich op nakoming of op schadevergoeding wenst te beroepen. De Hoge Raad heeft immers in het landmark-arrest Multi Vastgoed/ Nethou deze keuzevrijheid onderstreept en daarbij aangegeven dat dat alleen anders kan zijn wanneer een keuze voor nakoming naar maatstaven van redelijkheid en billijkheid onaanvaardbaar zou zijn. ${ }^{19}$ Daarbij geldt dat gedeeltelijke nakoming niet als nakoming kan worden beschouwd. Maar wat nu als er een relatief kleine tekortkoming plaatsvindt die niet tot kwantificeerbare schade bij de schuldeiser leidt, terwijl het afdwingen van nakoming tot hoge kosten bij de schuldenaar leidt?

Hier speelt de evenwichtskwestie wederom een voorname rol. Een belangrijk praktisch terrein waar deze kwestie speelt, is - zoals reeds voortvloeit uit het genoemde voorbeeld - de aannemings- en bouwbranche. De schuldenaar (de aannemer) wil niet in het kader van een geringe afwijking van de in de opdracht vermelde specificaties torenhoge extra kosten maken om de opdracht alsnog volgens de specificaties te vervullen en art. 7:759 lid 2 BW lijkt de aannemer daarbij ook terzijde te staan. ${ }^{20}$ Men denke ook aan de Engelse zaak Ruxley Electronics v. Forsyth, waarbij een net iets te ondiep zwembad werd gebouwd. ${ }^{21}$ In dat geval vorderde de opdrachtgever geen herstel, maar vervangende schadevergoeding, hetgeen een bedrag zou betekenen ter hoogte van de oorspronkelijke aanneemsom (omdat het herstel van het tekortschieten zou betekenen dat het gehele zwembad opnieuw zou moeten worden herbouwd). Het klinkt ook onredelijk om de aannemer in het geval van een klein gebrek het vel over de oren te trekken. Dat is in het Engelse recht dan ook niet gebeurd.

Niettemin lijkt het remediearsenaal van de schuldeiser naar Nederlands recht, afgezien van art. 7:759 lid 2 BW, hem wel een goed eind op weg te helpen. Dat geldt niet alleen voor het zojuist besproken recht op nakoming, maar ook voor bijvoorbeeld het recht op ontbinding. In beginsel geeft volgens art. 6:265 BW immers elke tekortkoming recht op ontbinding. De tenzij-formule biedt wel een ontsnapping voor de schuldenaar, maar deze zal dan moeten aanvoeren dat de tekortkoming van te geringe betekenis is om de ontbinding te rechtvaardigen. ${ }^{22}$ Daarvan is niet snel sprake. Dezelfde uitgangspunten gelden voor het vorderen van vervangende schadevergoeding ex art. 6:87 BW.

Het uitgangspunt dat de schuldeiser in dit soort gevallen een sterke bescherming geniet, is niet zo vreemd in het licht van het adagium waarmee deze paragraaf begon. Een schuldeiser moet enerzijds niet met lege handen staan als hij geconfronteerd wordt met wanprestatie, ook al is het een geringe. Belangrijker is mijns inziens nog dat de schuldenaar niet het idee moet krijgen dat hij het privaatrecht achter zich heeft als hij overweegt om het - bijvoorbeeld uit het oogpunt van kostenbesparing - niet zo nauw te nemen met de contractuele afspraken. Het juiste moment om die afweging te maken is idealiter in de onderhandelingsfase voorafgaand aan de sluiting. Als er een onverwachte tegenslag tijdens de uitvoering van de opdracht optreedt, dan moet daarover direct met de opdrachtgever worden gecommuniceerd. Het gaat in beginsel niet aan dat de schuldenaar zelfstandig een beslissing neemt om af te wijken van contractuele specificaties en dan achteraf het argument kan inzetten dat de afwijking toch niet zoveel voorstelt. Daarbij wordt de opdrachtgever ook geholpen door art. 7:760 lid $1 \mathrm{BW}$.

Het lijkt erop dat de Hoge Raad de balans op dit punt toch weer een beetje in beweging zet in het voordeel van de schuldenaar. In zijn arrest van 21 april 2017 vernietigt de Hoge Raad een arrest van het Gerechtshof Amsterdam, waarin het hof in een verbouwingszaak de opdrachtgever gelijk gaf in het vorderen van vervangende schadevergoeding bij een relatief mineur gebrek in de verbouwing van een keuken. ${ }^{23}$
18. M. van Kogelenberg, Winstafdracht na wanprestatie rechtsvergelijkend bezien; wankelend over de compensatiedrempel van het schadevergoedingsrecht, WPNR 2014/7031, p. 836-846.

19. HR 5 januari 2001, NJ 2001/79 (Multi Vastgoed/Nethou).

20. Denk overigens ook in het geval van consumentenkoop aan art. 7:21 lid 4 en 5 BW.
21. Ruxley Electronics and Construction Ltd v. Forsyth [1996] AC 344; zie ook M. van Kogelenberg, Het glas is halfvol ... of halfleeg?, NTBR 2009, afl. 3, p. 100-106.

22. Asser/Hartkamp \& Sieburgh 6-III 2014/684; zie ook HR 4 februari 2000, NJ 2000/562 (Mol/Meijer).

23. HR 21 april 2017, ECLI:NL:HR:2017:743 (X/Y). 


\section{Maandblad \\ Vermogensrecht}

Het ging in deze zaak onder meer om een verbouwing van een keuken, waarbij de keuken volgens de opdrachtgever uiteindelijk een kleine knik bevatte en licht afliep. Dit zou in strijd zijn met contractuele afspraken en met de zogenaamde Staburichtlijn, hoewel deze laatste richtlijn niet rechtstreeks op de overeenkomst van toepassing was.

De opdrachtgever vorderde in eerste instantie herstel, later vervangende schadevergoeding ter hoogte van de kosten van herstel om de keuken te laten egaliseren. Het zou er dan min of meer op neerkomen dat de keuken opnieuw moest worden geplaatst. De rechtbank wijst de vordering(en) af om een hier niet ter zake doende reden. Het Gerechtshof Amsterdam echter wijst de vordering ten aanzien van de herstelkosten voor de keuken toe en motiveert dit oordeel met het argument dat herstel nu eenmaal kostbaar kan zijn. ${ }^{24}$

Tegen dat oordeel gaat de aannemer in cassatie en met succes. De aannemer betoogt dat het hof onvoldoende is ingegaan op de stelling dat de eventuele tekortkoming van een zo ondergeschikte betekenis is dat dit omzetting in een verbintenis tot het betalen van vervangende schadevergoeding niet rechtvaardigt, dan wel dat een volledige vergoeding van herstelkosten naar maatstaven van redelijkheid en billijkheid onaanvaardbaar is. De Hoge Raad oordeelt dat het hof zijn oordeel onvoldoende heeft gemotiveerd, zeker omdat het hof heeft geoordeeld dat niet ter zake doet dat het gevorderde bedrag niet in relatie staat tot de omvang van de oorspronkelijke aanneemsom.

Hoewel de Hoge Raad hier een oordeel geeft gebaseerd op een motiveringsklacht, mag voorzichtig worden geconcludeerd dat hij erop wijst dat de mogelijkheden van de schuldeiser om zich op contractenrechtelijke remedies te beroepen niet oneindig zijn. In ieder geval zal beter moeten worden gemotiveerd waarom in een dergelijk geval substantiële herstelkosten met succes kunnen worden gevorderd, terwijl het resultaat mogelijkerwijs een minimale verbetering in prestatie teweegbrengt.

Interessant is in dit gevalstype de preventieve werking van een sterk recht op nakoming of vervangende schadevergoeding. Een aannemer mag niet in de verleiding worden gebracht op basis van overwegingen van kostenbesparing zich niet aan contractuele specificaties te houden. Het zij nogmaals benadrukt dat dit in de zojuist besproken zaak niet aan de orde is. Als de aannemer in het algemeen echter te snel de stelling kan betrekken dat zijn tekortkoming niet zoveel voorstelt in het licht van het gehele contract, wordt de vertrouwensband te zeer op de proef gesteld. Daar staat wel tegenover dat in een concreet geval van tekortschieten steeds opnieuw moet worden bezien hoe daarop kan en mag worden gereageerd. Het is immers ook

24. Hof Amsterdam 19 mei 2015, ECLI:NL:GHAMS:2015:1923(Y/X). ongewenst wanneer de schuldeiser financieel (groot) voordeel kan hebben van een wanprestatie. ${ }^{25}$

In het kader van het vinden van een balans tussen schuldeiser en schuldenaar kom ik nog even terug op de zaak Ruxley. Daar wees de rechter in eerste aanleg een relatief gering bedrag aan 'loss of amenity' (vergoeding van immateriële schade) toe vanwege het feit dat de opdrachtgever een iets ondieper zwembad had gekregen dan was afgesproken. De grondslag voor deze vergoeding is moeilijker te duiden. Die is in de betreffende zaak ook niet nader onderzocht, omdat hierover niet is geklaagd bij het House of Lords. Het lijkt erop dat de rechter in die kwestie enige waarde toekent aan het gegeven dat een contractuele prestatie niet geheel correct vervuld is, ook al is er geen kwantificeerbare (vermogens)schade. Het toekennen van een dergelijke kleine - wellicht zelfs symbolische - vergoeding kan worden gezien als de erkenning van het belang van de contractuele band en de waardering van het nakomen van de daaruit voortvloeiende verplichtingen. Een directe parallel met het Nederlandse recht is niet zo gemakkelijk te vinden, maar het Nederlandse recht kent in bepaalde gevallen wel het recht op vergoeding van gemist immaterieel voordeel bij wanprestatie. ${ }^{26} \mathrm{Als}$ het gaat om het handhaven van de belangenbalans tussen schuldeiser en schuldenaar, is een dergelijke oplossingsrichting voorstelbaar.

\section{Conclusie}

Aan het slot van deze bijdrage kom ik tot de conclusie dat mijn proefschrift enerzijds (mijns inziens) terecht heeft blootgelegd dat het privaatrecht voldoende zekerheden moet inbouwen die misbruik van het vertrouwen in de contractsband door de schuldenaar voorkomen c.q. afschrikken, zeker in het geval van opzettelijk tekortschieten. Anderzijds levert een kritische terugblik ook het voortschrijdende inzicht op dat niet te veel uit het oog moet worden verloren dat de schuldeiser op zijn beurt geen misbruik mag en moet kunnen maken van de aan hem toegekende rechten in het kader van wanprestatie in het algemeen, zelfs niet als opzettelijk tekortgeschoten wordt.

Een contract bindt partijen en noopt partijen tot nakoming van de uit het contract voortvloeiende verbintenissen. Uitgangspunt moet zijn dat partijen in beginsel deze verplichting blijven voelen als na het sluiten van het contract incentives opkomen die een van de partijen ertoe kunnen verleiden het niet zo nauw te nemen met de contractuele belofte. Een goed voorbeeld is de eerder besproken onderverhuurkwestie. De incentives die voortvloeien uit het contractuele remedierecht

25. Zie voor een Canadees perspectief A.R. Hassell, Nominal Damages Awarded to Plaintiff for Failure to Meet Commercial Contract Specifications - Diotte v. Consolidated Dev. Co., 2014 CarswellNB 410 (Can. N.B.C.A.) (WL), Suffolk Transnational Law Review (38) 2015, p. 207-219.

26. Zie daarover HR 28 januari 2005, ECLI:NL:HR:2005:AR6460, NJ 2008/55 (Burger/Brouwer Motor B.V.), o.m. nader besproken in een mooie en recente rechtsvergelijkende bijdrage, M.Th. Beumers, Schadevergoeding voor genotsderving en teleurstelling, NTBR 2016/25, afl. 6, p. 169-178. 
moeten trouw aan het gegeven woord in beginsel stimuleren: denk in het genoemde voorbeeld aan een gemakkelijk toegankelijk recht op ontbinding van de oorspronkelijke huurovereenkomst.

De positie van de schuldeiser moet echter ook met voorzichtigheid worden bezien. Hij mag op zijn beurt ook niet te gemakkelijk voordeel trekken uit zijn 'slachtofferrol'. Daarbij is allereerst van belang dat helder is wat precies de contractuele verplichtingen zijn - zie de overboekingskwestie -, maar ook de notie dat de schuldenaar niet te gemakkelijk 'gratis' kan wanpresteren - zie de kwestie inzake de 'kleine' tekortkoming.

Uit deze bijdrage en uit het proefschrift blijkt ook dat de vraag hoe remedies na een opzettelijke tekortkoming moeten worden vormgegeven, een vraag is waarop geen algemeen antwoord te geven is. Het zijn de zojuist geschetste lijnen waarlangs op casusniveau een concrete oplossing moet worden gezocht, waarbij wel geldt dat het 'opzetaspect' een rol kan vervullen bij de invulling van de toe te passen remedie(s).

Ten slotte past ook enige bescheidenheid wat betreft de positie en de rol van het contractenrecht. Veel problemen lossen zich vanwege gemeenschappelijke belangen - bijvoorbeeld economische - ook buiten het formele recht wel op. In de overboekingssfeer zien we dat veel passagiers zich graag laten uitkopen. Het leidt zelden tot onverkwikkelijke situaties. Een degelijk beeld van waartoe partijen zich verplichten en welke risico's zij lopen als zij dat niet doen en zéker als zij dat opzettelijk niet doen, is echter essentieel om het nodige vertrouwen te scheppen, waarbinnen de noodzaak om uiteindelijk een geschil voor de rechter op te lossen naar de achtergrond verdwijnt. 